\title{
ANALIZA UWARUNKOWAŃ INWESTYCYJNYCH NA RYNKU DIAMENTÓW
}

\begin{abstract}
W artykule zaprezentowano tendencje rozwojowe na rynku diamentów, brylantów (oszlifowanych i wypolerowanych diamentów), a także na rynku biżuterii diamentowej. Rynek diamentów należał do 2011 r. do jednego z najszybciej wzrastających segmentów inwestycji alternatywnych, głównie ze względu na poszukiwanie przez inwestorów możliwości lokowania nadwyżek finansowych w innych obszarach rynku finansowego niż rynek akcji, obligacji, towarów czy walut. Jako jeden z elementów inwestycji alternatywnych diamenty mogą być wykorzystywane do dywersyfikacji portfeli inwestycyjnych zgodnie z nowoczesną teorią portfelową. Inwestycje na rynku diamentów obejmują także zakup akcji spółek działających w tym segmencie, czyli firm wydobywczych i pośredników. Rynek diamentów jest jednym z nielicznych rynków inwestycji alternatywnych z rozwiniętym systemem giełd diamentów, a także mającym bogatą klasyfikację handlowanych obiektów.

$\mathrm{W}$ artykule ukazano wybrane indeksy stosowane na rynku diamentów, a także stopy zwrotu z akcji wybranych kopalni diamentów. Przeprowadzono również analizę stóp zwrotu z indeksu Diamond Prices Index (DPI) z indeksem WIG20 w okresie styczeń 2006 - lipiec 2014, a także regresję liniową i zastosowano metodę wielomianową indeksu DPI w tym samym okresie. Uzyskane wyniki jednoznacznie wskazują, że analizowanym okresie stopa zwrotu z indeksu DPI była dodatnia i wynosiła $58,1 \%$, podczas gdy stopa zwrotu z polskiego indeksu akcji WIG20 była ujemna i równa $14,4 \%$. Z kolei wyniki regresji indeksu DPI metodą wielomianową są zdecydowanie lepsze - współczynnik $R^{2}$ wynosił 0,92 , podczas gdy w metodzie regresji liniowej - 0,66.
\end{abstract}

Słowa kluczowe: rynek diamentów, diamenty, rynek brylantów, brylanty, biżuteria diamentowa, giełdy diamentów

Wzrost zamożności społeczeństwa powoduje poszukiwanie przez inwestorów innych kierunków inwestowania niż powszechnie akceptowane rynki akcji, obligacji czy też towarów (commodities). Jednym $\mathrm{z}$ takich rynków jest rynek kamieni szlachetnych ${ }^{2}$, szczególnie rynek diamentów otwierający przed inwestorami nowe możliwości lokowania środków finansowych. Rynek ten charakteryzuje się długim horyzontem inwestycyjnym, natomiast nie jest zarezerwowany wyłącznie dla uczestników dysponujących dużymi wielkościami płynnych aktywów. Dodatkowo, oprócz dodatnich stóp zwrotu, inwestorzy uzyskują doznania estetyczne związane $\mathrm{z}$ podziwianiem nabytych kamieni ${ }^{3}$. Rynek pole-

\footnotetext{
${ }^{1}$ Dr hab. Krzysztof Borowski, Instytut Bankowości i Ubezpieczeń Gospodarczych, Szkoła Główna Handlowa, ul. Madalińskiego 6/8, 02-554 Warszawa, e-mail:krzysztof.borowski@ @gh.waw.pl

${ }^{2}$ Kamieniami szlachetnymi są: diament, rubin, szafir, szmaragd. Na podstawie: A. Eid, Mineraty i skamieniałości, Arkady, Warszawa 2000.

${ }^{3} \mathrm{~K}$. Borowski, M. Bombol, Inwestycje na rynku wina inwestycyjnego oraz diamentów, [w:] Badania polskiej klasy wyższej. Problemy, diagnozy, dylematy, red. M. Bombol, Oficyna Wydawnicza SGH, Warszawa 2012, s. $225-238$.
} 
rowanych diamentów (brylantów) zaczął gwałtownie się rozwijać wraz z wybuchem kryzysu finansowego w 2007 r. $^{4}$ - znaczna część inwestorów uznała ten fragment rynku inwestycji alternatywnych za bezpieczną przystań dla swoich środków finansowych.

Celem artykułu jest zaprezentowanie najnowszych tendencji dominujących na światowym rynku diamentów, a także porównanie stóp zwrotu na rynku diamentów i indeksu WIG20.

\section{PODSTAWOWE INFORMACJE O DIAMENTACH}

Brylanty to fachowa nazwa diamentów o szlifie brylantowym. Naturalne diamenty w formie nieobrobionej, a więc zaraz po wydobyciu, są niemalże matowe, bez połysku. Odpowiedni szlif wydobywa z nich życie, światło, blask. Do najważniejszych czynników wpływających na jakość i wartość brylantów zalicza się cztery cechy, które w literaturze przedmiotu określa się jako „,4C",

- $\quad$ czystość (clarity) - opisana za pomocą skali od LC (najczystsze) do P3.;

- masa (carat) - jednostką masy diamentu jest karat metryczny, równoważny $200 \mathrm{mg}$ (1/5 g). Masę podaje się z dokładnością do dwóch miejsc po przecinku. Przyjęto oznaczenie masy w postaci skrótu "ct";

- barwa (colour) - stosuje się określenie literowe barwy od B (bezbarwny) do Z (jasnożółty)

- $\quad$ szlif $(c u t)$ - w terminologii jubilerskiej brylant to okrągły diament o pełnym szlifie brylantowym, to znaczy zawierający nie mniej niż 57 faset $(56+1)^{7}$. Jest to szlif stosowany od połowy lat pięćdziesiątych XX w. Każdy inny, tak zwany przejściowy, obniża wartość diamentu ${ }^{8}$.

Między cenami diamentów a ich wagą, a także między barwą i czystością nie występuje zależność liniowa. Im większa masa diamentu, tym wyższa cena jednego karata9. Analogiczną zależność można podać dla zależności ceny diamentu od jego barwy i czystości (por. tab. 1, 2).

\footnotetext{
${ }^{4}$ E. Erheriene, Diamond prices decline for sixth month in row, ,Wall Street Journal” 18.09.2014, s. 22.

${ }^{5}$ Skrót 4C pochodzi od angielskich nazw czterech wyrazów oznaczających najważniejsze cechy diamentu.

${ }^{6}$ Klasy barw według Gemological Institute of America (GIA), zgodne z Polską Normą PN-MI 7007:2002.

${ }^{7}$ Faseta - wieloznaczne pojęcie, używane w budownictwie i jubilerstwie. Inaczej faza - ukos, ucios, skośne ścięcie narożnika lub graniastej krawędzi, w celu ochrony przed uszkodzeniem od przypadkowego uderzenia. W jubilerstwie to oszlifowana powierzchnia kamienia szlachetnego. Na przykład w szlifie brylantowym okrągłym wyróżnia się następujące elementy: korona (tafla, faseta główna korony, faseta tafli), rondysta (fasety rondysty korony), pawilon (fasety rondysty pawilonu, faseta główna pawilonu, kolet). Przykładami szlifów diamentowych mogą być między innymi: okragły, markiza, gruszka, princessa, serce, owal, szmaragd, bagiet$\mathrm{ka}$, trylion. Szlify współczesne charakteryzują się 57 fasetami. Na podstawie strony internetowej: http://pl.wikipedia.org/wiki/Faseta (dostęp: 22.07.2014).

${ }^{8}$ Więcej informacji dotyczących wyceny diamentów należnych do różnych klas (barwa, czystość, waga) można znaleźć między innymi na stronie internetowej: http://www.thediamondbuyingguide.com/diamondprices.html (27.02.2012).

${ }^{9}$ Borowski K., Nowe kierunki bankowości inwestycyjnej - rynek diamentów naturalnych, „Studia i Prace Kolegium Zarządzania i Finansów" 2007/81, s. 77-95.
} 
Tabela 1. Zależność średniej ceny diamentów od jego wagi (ceny z 31.08.2013) - pozostałe parametry diamentów takie same

Table 1. The dependence of the average price of diamonds from its weight (price per day 31.08.2013) - the other parameters of diamonds are the same

\begin{tabular}{|r|r|r|}
\hline Ilość karatów & Cena diamentu (USD) & $\begin{array}{c}\text { Wielokrotność ceny diamentu } \\
\text { o wadze 0,5 karata }\end{array}$ \\
\hline 0,5 & 9 & 3,0 \\
\hline 1 & 27 & 10,8 \\
\hline 3 & 97 & 16,0 \\
\hline 5 & 144 & \\
\hline
\end{tabular}

Źródło: Bain \& Co., The Global Diamond Report 2013, Nowy Jork 2013, s. 43 (dostęp 12.10.2014).

Tabela 2. Cena jednego karata diamentów w zależności od barwy i czystości (ceny z 31.08.2013) diamenty o tej samej wadze

Table 2. The price of one carat diamonds depending on the color and clarity (prices on the 31.08.2013) - diamonds of the same weight

\begin{tabular}{|l|r|rr|}
\hline Barwa/czystość & Cena 1 karata & \multicolumn{2}{|c|}{$\begin{array}{c}\text { Wielokrotność ceny } \\
\text { diamentu K/SI2 }\end{array}$} \\
\hline K/SI2 & 4 & 1,8 \\
\hline H/VS2 & 7 & 2,8 \\
\hline F/WS2 & 11 & 6,8 \\
\hline D/IF & 27 & & \\
\hline
\end{tabular}

Źródło: Bain \& Co., The Global Diamond Report 2013, Nowy Jork, 2013, s. 43 (dostęp 12.10.2014).

Około $70 \%$ sprzedawanych diamentów znajduje zastosowanie w przemyśle, pozostałe $30 \%$ wydobytych diamentów, o najlepszych parametrach z grupy 4C, trafia do przemysłu jubilerskiego. Większość diamentów w obrocie detalicznym stanowi część zaręczynowego pierścionka - która kobieta nie marzy o otrzymaniu pierścionka właśnie $\mathrm{z}$ brylantem ${ }^{10}$ ? To właśnie diament jako najtrwalszy materiał ma dowodzić trwałości złożonych zobowiązań. Odkąd zaczęto zdawać sobie sprawę z tego, że diament - oprócz szczególnej wartości estetyczno-dekoracyjnej czy artystycznej - może mieć również wartość materialną dającą się wyrazić równoważnikiem pieniężnym, na przykład jako lokata kapitału, gwałtownie zaczęto porządkować światowy obrót diamentami oraz klasyfikować jego cechy jakościowe, od których - podobnie jak w wypadku wszystkich rzeczy powstających w przyrodzie w sposób naturalny - zależy jego wartość. Obecnie światowy obrót diamentami jest już skategoryzowany, a wyznaczana wartość ściśle określona. Na świecie powstały też specjalistyczne indeksy (podobne do giełdowych) obrazujące cenę określonej kategorii diamentów.

\footnotetext{
${ }^{10}$ Moda na wręczanie zaręczynowego pierścionka z brylantem została rozpowszechniona w Stanach Zjednoczonych w latach sześćdziesiątych XX w., skąd przeniosła się do innych krajów.
} 


\section{2. ŚWIATOWY RYNEK DIAMENTÓW I BIŻUTERII ZAWIERAJĄCEJ DIA- MENTY}

Tempo wzrostu światowego rynku diamentów w 2003 r. wyniosło 3\%. Szacuje się, że w 2014 r. będzie ono równe 4-4,5\%. W 2013 r. cena surowych i nieoszlifowanych diamentów wzrosła średnio o $10 \%$, głównie za sprawą wzrostu zainteresowania wyrobami jubilerskimi z udziałem diamentów w Stanach Zjednoczonych i Chinach. Jednak w tym czasie pogorszyła się kondycja na rynku indyjskim, do czego niewątpliwie przyczyniła się dewaluacja lokalnej waluty. Wartość wydobycia diamentów na świecie w 2012 r. wyniosła 145 mln karatów, czyli o 12 mln karatów więcej niż w 2010 r. Szacuje się, że w 2014 r. wartość wydobycia diamentów będzie równa 160 mln karatów, a w kolejnych latach będzie zwyżkować - i tak, w latach 2016, 2018 i 2020 wyniesie odpowiednio: 170, 173 i 175 mln karatów (rys. 1).

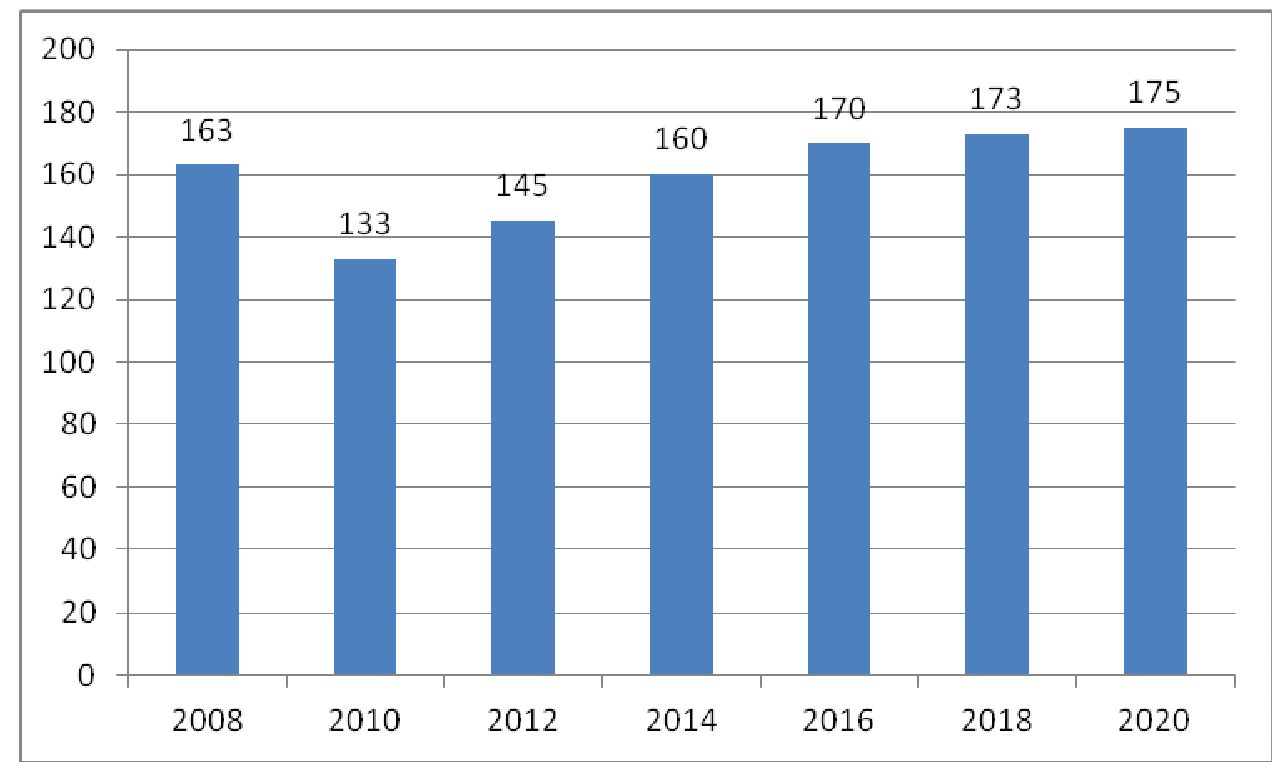

Rys. 1. Wydobycie diamentów na świecie w mln karatów

Fig. 1. Mining of diamonds in the world in million of carats

Źródło: Euromonitor, Bain \& Co., Rapaport, Nowy Jork 2014, (dostęp 12.10.2014).

Około $80 \%$ rynku wydobycia skoncentrowane jest w rękach pięciu firm: Alrosa, BHP Billiton, De Beers, Harry Winston Diamond ${ }^{11}$ i Rio Tinto ${ }^{12}$. W 2012 r. udział rosyjskiej spółki Alrosa w wydobyciu nieoszlifowanych diamentów wynosił $27 \%$ światowej produkcji $(34,4 \mathrm{mln}$ ct). Z kolei pod względem przychodów uzyskiwanych ze sprzedaży diamentów na pierwszym miejscu w 2012 r. uplasowały się kopalnie De Beers (5,5 mld USD) (tab. 3, 4).

\footnotetext{
${ }^{11}$ Od 2013 r. firma nosi nazwę Dominion Diamonds.

${ }^{12} \mathrm{Na}$ podstawie strony internetowej: http://www.forbes.pl/diamenty-w-odwrocie-juz-wkrotce-zacznie-brakowacdiamentow,artykuly,165840,1,1.html (dostęp: 19.09.2014).
} 
Tabela 3. Udział poszczególnych firm w wydobyciu nieoszlifowanych diamentów (\%)

Table 3. The share of individual companies in the mining of rough diamonds

\begin{tabular}{|l|r|r|r|r|r|r|r|}
\hline \multicolumn{1}{|c|}{ Nazwa firmy } & \multicolumn{1}{c|}{$\mathbf{2 0 0 6}$} & \multicolumn{1}{c|}{$\mathbf{2 0 0 7}$} & \multicolumn{1}{c|}{$\mathbf{2 0 0 8}$} & \multicolumn{1}{c|}{$\mathbf{2 0 0 9}$} & $\mathbf{2 0 1 0}$ & \multicolumn{1}{c|}{$\mathbf{2 0 1 1}$} & $\mathbf{2 0 1 2}$ \\
\hline Alrosa & 21 & 21 & 23 & 27 & 27 & 28 & 27 \\
\hline De Beers & 29 & 30 & 30 & 20 & 26 & 26 & 22 \\
\hline Rio Tinto & 20 & 15 & 13 & 12 & 11 & 10 & 10 \\
\hline BHP Billiton & 1 & 2 & 2 & 3 & 2 & 2 & 1 \\
\hline Dominion Diamond & 2 & 3 & 2 & 2 & 2 & 2 & 2 \\
\hline Pozostali & 27 & 29 & 30 & 36 & 32 & 32 & 38 \\
\hline
\end{tabular}

Źródło: Bain \& Co., The Global Diamond Report 2013, Nowy Jork, 2013, s. 9, (dostęp 12.10.2014).

Tabela 4. Udział poszczególnych firm w przychodach ze sprzedaży nieoszlifowanych diamentów (\%)

Table 4.The share of individual companies in the revenues from the sale of rough diamonds

\begin{tabular}{|c|c|c|c|c|c|c|c|}
\hline Nazwa firmy & 2006 & 2007 & 2008 & 2009 & 2010 & 2011 & 2012 \\
\hline Alrosa & 24 & 22 & 22 & 29 & 27 & 24 & 30 \\
\hline De Beers & 47 & 42 & 42 & 45 & 41 & 36 & 37 \\
\hline Rio Tinto & 6 & 7 & 6 & 6 & 6 & 4 & 5 \\
\hline BHP Billiton & 4 & 4 & 4 & 10 & 8 & 5 & 4 \\
\hline Dominion Diamond & 3 & 3 & 2 & 3 & 2 & 2 & 2 \\
\hline Pozostali & 16 & 22 & 24 & 7 & 16 & 29 & 22 \\
\hline
\end{tabular}

Źródło: Bain \& Co., The Global Diamond Report 2013, Nowy Jork 2013, s. 10, (dostęp 12.10.2014)

Firmy Alrosa i De Beers odnotowały w 2012 r. najwyższą wartość zysku zarówno EBIT (zysk operacyjny), jak i EBIT na jeden karat. Zysk EBIT dla Alrosy i De Beers był równy 1579 mln USD i 818 mln USD, a zysk na jeden kart odpowiednio: 46 USD i 29 USD (tab. 5).

Tabela 5. Zysk EBIT i EBIT/ct wśród największych wydobywców diamentów w 2012 r.

Table 5. EBIT and EBIT/ct among the largest diamond miners in 2012

\begin{tabular}{|l|r|r|}
\hline \multicolumn{1}{|c|}{ Nazwa firmy } & EBIT w mln USD & \multicolumn{1}{c|}{ EBIT/ct } \\
\hline Alrosa & 1579 & 46 \\
\hline De Beers & 818 & 29 \\
\hline Rio Tinto* & -65 & -5 \\
\hline BHP Billiton* & -157 & -108 \\
\hline Dominion Diamond* & 48 & 17 \\
\hline
\end{tabular}

*uwzględniono tylko działalność firmy związaną z wydobyciem diamentów, pomijając inne Źródło: Bain \& Co., The Global Diamond Report 2013, Nowy Jork, 2013, s. 10, (dostęp 12.10.2014). 
Według rosyjskiej spółki wydobywającej diamenty Alrosa światowe wydobycie diamentów w 2017 r. szacowane jest na 166 mln karatów, z czego 109 mln produkowanych będzie przez cztery największe kopalnie, $46 \mathrm{mln}$ przez pozostałe firmy, a 11 będzie pochodzić z depozytów (rys. 2).

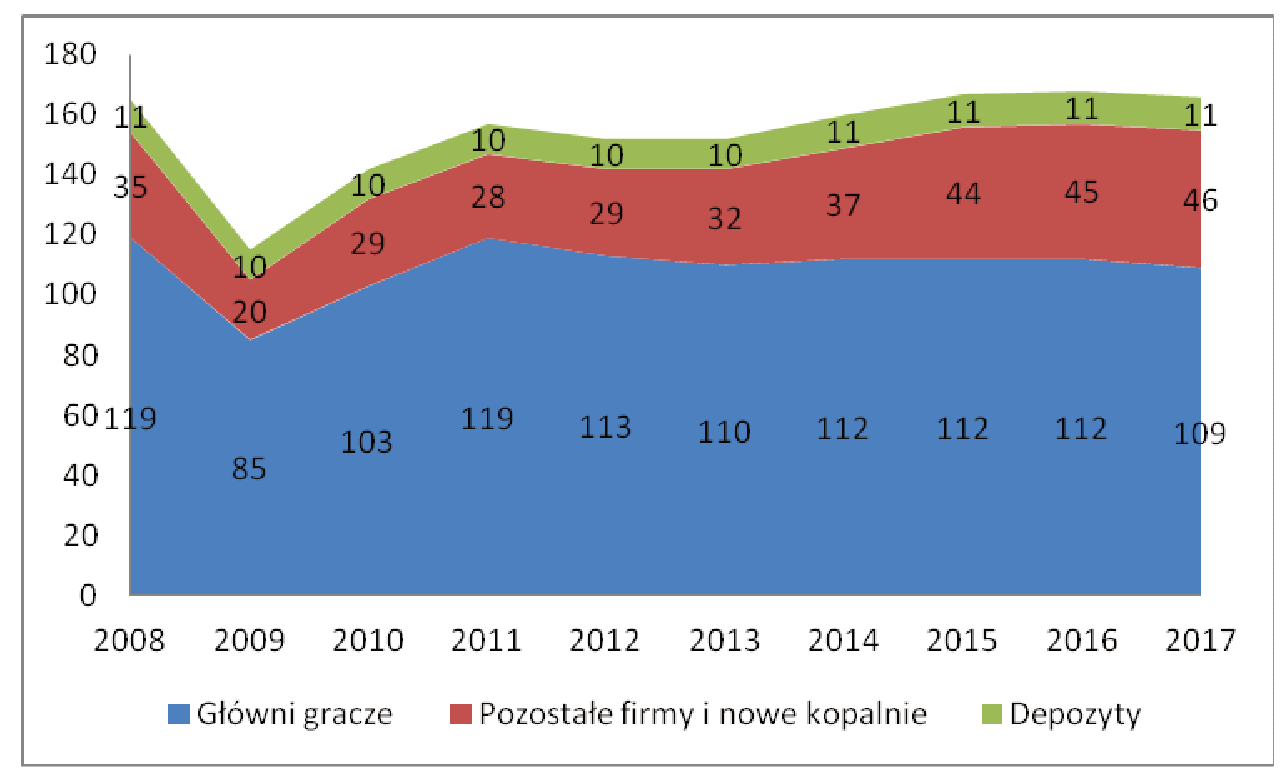

Rys. 2. Światowe wydobycie diamentów według Alrosy w latach 2008-2018 w mln karatów (prognoza obejmuje lata 2014-2018)

Fig. 2. World diamond mining in the years 2008-2018 in million of carats (forecast covers the period from 2014 to 2018) by Alrosa

Źródło: Raport o rynku diamentów ze spółki Alrosa, (dostęp 12.10.2014).

Wzrost cen na rynku diamentów w latach 2014-2018 będzie podsycany dzięki nadwyżce popytu na nieoszlifowane diamenty nad ich podażą. I tak, według danych rosyjskiej spółki wydobywającej diamenty Alrosa w 2018 r. popyt wyniesie 18,9 USD/ct przy podaży 14,4 USD/ct (rys. 3). 


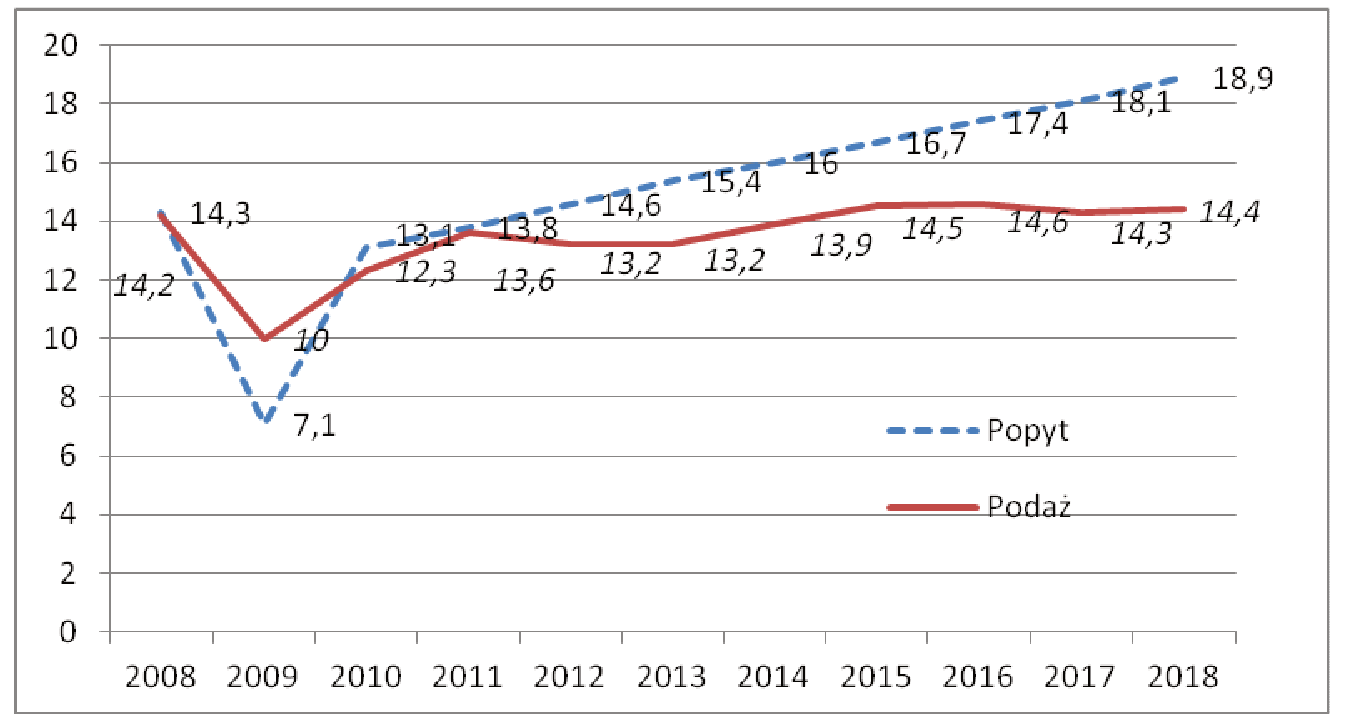

Rys. 3. Popyt i podaż na rynku nieoszlifowanych diamentów USD/ct (według cen z 2008 r.: 86,9 USD/ct). Prognoza dotyczy lat 2014-2018

Fig. 3. Demand and supply of rough diamonds on the market in USD/ct (according to prices in 2008: 86.9 USD/ct). Forecast covers the years 2014-2018

Źródło: Raport o rynku diamentów ze spółki Alrosa, (dostęp 12.10.2014).

Wartość całego rynku biżuterii na 16 największych rynkach wykazuje tendencję wzrostową od 2006 r., kiedy to wyniosła 119 mld USD, aby na koniec 2013 r. osiągnąc poziom 166 mld USD. Według szacunków wartość rynku biżuterii na koniec 2014 r. ma ukształtować się na poziomie 179 mld USD (rys. 4). Największy udział wyrobów z brylantami w sprzedaży biżuterii w 2013 r. miały rynki w Stanach Zjednoczonych i Japonii, gdzie przekroczył $50 \%$, podczas gdy w Indiach w tym samym czasie wyniósł on $20 \%$ rynku. Wartość rynku biżuterii brylantowej wynosiła na koniec 2012 r. 72,1 mld USD i była większa o prawie $2 \%$ od wartości rynku z 2011 r. (tab. 6). Do największego przyrostu wartości w łańcuchu produkcji biżuterii diamentowej w 2012 r. doszło w samym procesie tworzenia biżuterii z oszlifowanych i wypolerowanych diamentów (+24,6 mld USD) i sprzedaży detalicznej biżuterii diamentowej (+24,9 mld USD). Szacuje się, że przeciętny wzrost ceny jednego karata między wydobyciem diamentu (w tym diamentów o zastosowaniu przemysłowym) a jego sortowaniem i zakwalifikowaniem do kategorii jubilerskiej jest około 1,8-krotny - w 2012 r. koszt wydobycia jednego karata wynosił 120 USD, a koszt jednego karata diamentów zakwalifikowanych jako jubilerskie był równy 200 USD. Po oszlifowaniu i polerowaniu przeciętna cena jednego karata w 2012 r. ukształtowała się na poziomie 900 USD, co oznacza 4,5-krotny wzrost ceny od stadium zakwalifikowania diamentu jako jubilerski. Tak więc przeciętna cena jednego karata diamentu oszlifowanego i wypolerowanego w stosunku do przeciętnej ceny wydobycia jednego karata jest większa 8,1-krotnie. Na marginesie należy zaznaczyć, że około: 
- 43-50\% wydobytych diamentów to nieoszlifowane diamenty przemysłowe,

- 50-57\% wydobytych diamentów to nieoszlifowane diamenty jubilerskie.

Po uwzględnieniu odpadów w procesie cięcia i polerowania, stanowiących około 31-39\% wydobytych diamentów, zaledwie około $20 \%$ wydobytych diamentów wchodzi w skład biżuterii diamentowej.

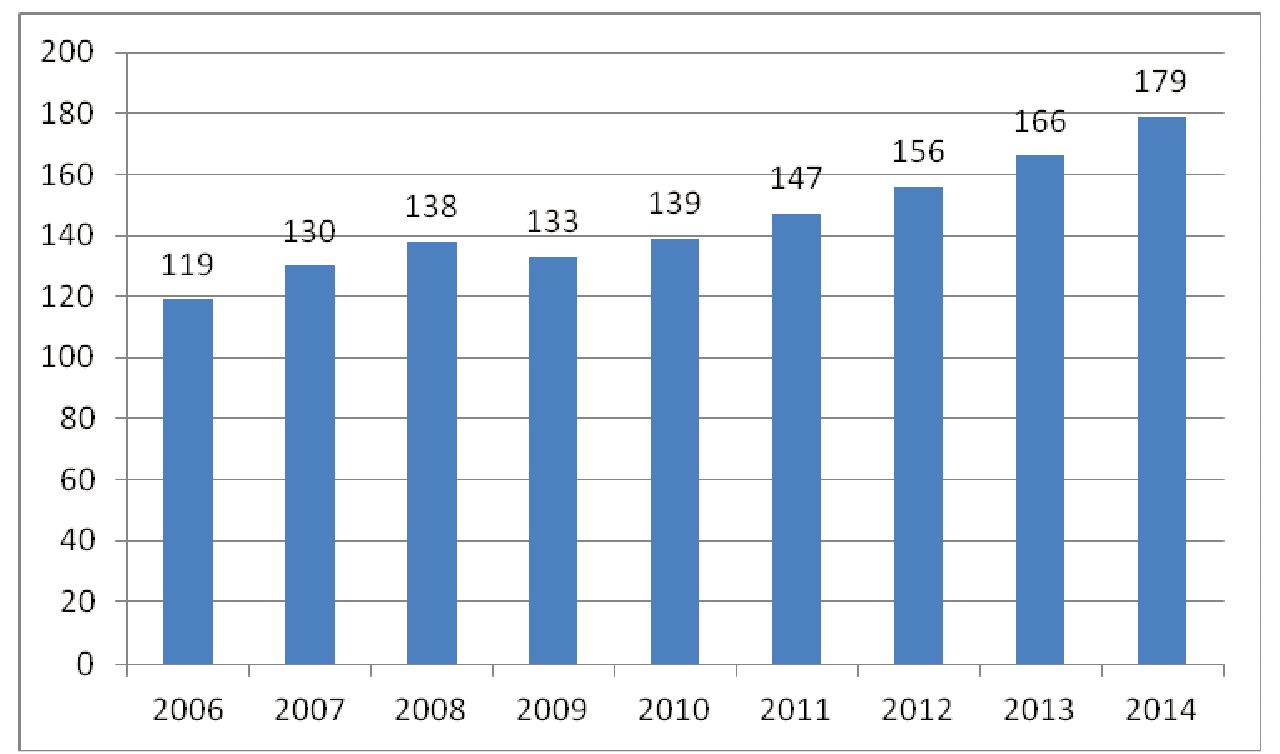

Rys. 4. Wartość rynku biżuterii na 16 największych rynkach (mld USD)

Fig. 4. The value of the jewelry market in the 16 largest markets (billion USD)

Źródło: Euromonitor, Bain \& CO, Rapaport, Nowy Jork, 2014, (dostęp 12.10.2014).

Tabela 6. Produkcja i sprzedaż nieoszlifowanych i oszlifowanych diamentów oraz biżuterii diamentowej (mld USD)

Table 6. Production and sales of rough and polished diamond and jewelery in billion USD

\begin{tabular}{|c|c|c|c|c|}
\hline Działalność & 2011 & 2012 & Zmiana & $\begin{array}{l}\text { Przyrost wartości } \\
\text { w } 2012 \text { r. }\end{array}$ \\
\hline Wydobycie i produkcja diamentów & 18 & 14,8 & $-17,8 \%$ & \\
\hline Sprzedaż diamentów nieoszlifowanych & 8,3 & 15,2 & $83,1 \%$ & 0,4 \\
\hline Cięcie i polerowanie diamentów & 22,6 & 20,7 & $-8,4 \%$ & 5,5 \\
\hline $\begin{array}{l}\text { Sprzedaż oszlifowanych i wypolero- } \\
\text { wanych diamentów }\end{array}$ & 23,6 & 22,6 & $-4,2 \%$ & 1,9 \\
\hline Wyrób biżuterii diamentowej & 46,3 & 47,2 & $1,9 \%$ & 24,6 \\
\hline $\begin{array}{l}\text { Sprzedaż detaliczna biżuterii diamen- } \\
\text { towej }\end{array}$ & 70,8 & 72,1 & $1,8 \%$ & 24,9 \\
\hline
\end{tabular}

Źródło: Bain \& Co., The Global Diamond Report 2013, Nowy Jork 2013, s. 3, (dostęp 12.10.2014). 
Według innych oszacowań tempo wzrostu rynku biżuterii diamentowej utrzymuje się na poziomie około 6,4\% rocznie, a w roku 2020 wyniesie około 247 mln karatów. W ujęciu wartościowym w 2015 r. popyt na biżuterię z diamentami będzie wart około 100 mld USD w porównaniu z 73,6 mld USD w 2010. Za takim scenariuszem rozwoju przemawia gwałtownie rosnący popyt ze strony powiększającej się klasy średniej w Chinach. Zdaniem firmy analitycznej Bain \& Co. taki trend będzie widoczny przynajmniej do $2020 \mathrm{r}^{13}$. W Chinach największe zainteresowanie w 2013 r. wzbudzały kamienie jednokratowe, a więc najbardziej popularne w Stanach Zjednoczonych, o barwie GJ (prawie bezbarwne) i o skali zanieczyszczeń SI2 (z nieznacznymi, ale dostrzegalnymi inkluzjami). Inną grupa poszukiwanych w Chinach kamieni były brylanty trzykaratowe. Tylko w Indiach najchętniej nabywane były kamienie $0,5-0,7 \mathrm{ct}$, przy znacznym spadku popytu na kamienie $0,3-0,4 \mathrm{ct}$.

Aktualnie wartość rynku diamentów w Polsce wyceniana jest na około 2,5 mld zł w wielkości tej zawiera się kilkusetmilionowa sprzedaż zegarków ${ }^{14}$. W naszym kraju sprzedaż diamentów prowadzą: Mennica Polska oraz mennice Skarbowa (oddziały w Warszawie i Wrocławiu) i Wrocławska (filie w Warszawie, Krakowie, Lublinie, Białymstoku, Opolu, Kielcach, Gdańsku i Katowicach). Od 2012 r. swoje przedstawicielstwo ma w Warszawie firma Diamonds International Corporation, będąca członkiem giełdy diamentowej w Antwerpii (Vereniging Beurs Voor Den Diamanthandel).

\section{NAJWIĘKSI PRODUCENCI DIAMENTÓW}

Największymi producentami diamentów są: Republika Południowej Afryki, Rosja, Bostwana oraz kraje Ameryki Łacińskiej ${ }^{15}$ - pozostałe dane zamieszczono w tabeli 7.

Tabela 7. Charakterystyka największych złóż diamentów na świecie

Table 7. Characteristics of the largest diamond deposits in the world

\begin{tabular}{|l|l|}
\hline \multicolumn{1}{|c|}{ Kraj/region } & \multicolumn{1}{c|}{ Krótka charakterystyka } \\
\hline Ameryka Łacińska & $\begin{array}{l}\text { W Brazylii w prowincji Minas Gerias w kilku miejscach (np. Dia- } \\
\text { mantina) odbywa się półlegalne wydobycie diamentów z napław } \\
\text { przez garimpeiros, w niektórych lokalizacjach wydobyciem zajmuje } \\
\text { się państwo, a eksploatacja jest bardziej intensywna - na przykład } \\
\text { w Rio Jequitinonha. Inne złoża diamentów znajdują się na terenie } \\
\text { Wenezueli i Gujany }\end{array}$ \\
\hline Afryka & $\begin{array}{l}\text { Najbardziej znane kopalnie diamentów znajdują się w Południowej } \\
\text { Afryce, gdzie pod koniec XIX wieku wybuchła diamentowa gorącz- } \\
\text { ka w: Jagersfontein, Dutoitspan, Bulrfontein, De Beers, Kimberly, } \\
\text { Wesselton, Premier, Finisch. Obecnie najbardziej wydajną kopalnią } \\
\text { w RPA jest Finisch, jak dotąd ostatnie odkryte łożysko diamentów } \\
\text { w RPA. Niektóre złoża zostały definitywnie zamknięte (Jagersfonte- } \\
\text { in, Kimberly), inne funkcjonują do dziś (Dutoitspan). Wydajność }\end{array}$ \\
\hline
\end{tabular}

\footnotetext{
${ }^{13}$ Na podstawie strony internetowej: http://www.ekonomia24.pl/artykul/706159,785085-Zloto-zdrozeje-w-2012-Ale-czas-na-diamenty.html (dostęp: 27.02.2014).

${ }^{14}$ P. Mazurkiewicz, Brylanty sq wieczne. I drożejq, „Rzeczpospolita”, 18.02.2014, s. B6.

${ }^{15} \mathrm{Na}$ podstawie strony internetowej: http://www.dicholding.com/pl/diament/ogolne-informacje/zoa-diamentow (dostęp: 27.07.2014).
} 


\begin{tabular}{|c|c|}
\hline & $\begin{array}{l}\text { kimberlitu w RPA jest } \mathrm{w} \text { granicach } 1 \text { karata diamentu na } 1 \text { tone } \\
\text { skały. W południowoafrykańskich kopalniach znaleziono na przy- } \\
\text { kład największy jak dotąd znaleziony surowy diament - Cullinan, } \\
\text { który w stanie surowym ważył ponad } 3000 \mathrm{ct} \text {. }\end{array}$ \\
\hline Australia & $\begin{array}{l}\text { Jest obecnie największym światowym producentem diamentów } \\
\text { jubilerskich. Eksploatacja diamentów odbywa się w pierwotnym } \\
\text { łożysku Argyle na pniu nazwanym AKL, który znajduje się } \\
\text { w zachodniej Australii w okolicach Kimberly. Pień AKI zawiera } \\
\text { diamenty o koncentracji do } 7 \text { ct z tony skały. }\end{array}$ \\
\hline Kanada & $\begin{array}{l}\text { Najmłodszym wielkim złożem diamentowym jest szyb Ekati leżący } \\
\text { na północy Kanady }\end{array}$ \\
\hline Rosja & $\begin{array}{l}\text { Bardzo bogate diamentowe łożyska w Rosji, z których największe } \\
\text { zostały odkryte w latach 1954-1959. Diamentonośne kominy znajdu- } \\
\text { ją się w Jakucji na Syberii. W tym regionie znaleziono kilkadziesiąt } \\
\text { kominów kimberlitowych, ale diamentonośnych jest tylko kilka. Do } \\
\text { najbardziej znanych należą złoża Mir i Udacznaja. Kamienie sa } \\
\text { przeciętnie większe niż w innych światowych lokalizacjach, a ich } \\
\text { jakość jest zazwyczaj dość wysoka. Zawartość diamentów w skale } \\
\text { określa się na 0,05-4,0 ct z tony, a około } 37 \% \text { diamentów nadaje się } \\
\text { do zastosowania w jubilerstwie. Diamenty wydobywa firma akcyjna } \\
\text { Alrosa, w której głównym udziałowcem jest państwo. Cześć diamen- } \\
\text { tów jest szlifowana bezpośrednio w Rosji, pozostałe sprzedaje się na } \\
\text { rynki światowe we współpracy z firmą De Beers }\end{array}$ \\
\hline Botswana & $\begin{array}{l}\text { Państwo graniczące z RPA ma własne złoża diamentów o wyjątko- } \\
\text { wej jakości. Występują tutaj komininy: Orapa, Jwaneng i Letlhekane. } \\
\text { Szyb Jweneng produkuje dzisiaj } 25 \% \text { światowej produkcji diamen- } \\
\text { tów jubilerskich }\end{array}$ \\
\hline Namibia & $\begin{array}{l}\text { Niezamieszkane wybrzeże Namibii było przez marynarzy nazywane } \\
\text { „Wybrzeżem kości”. Długo nikt nie wiedział, że właśnie pod pia- } \\
\text { skiem tego wybrzeża skrywa się wielka koncentracja diamentów. } \\
\text { Napływy Pomarańczowej rzeki wpływającej do Atlantyku przynosiły } \\
\text { na plażę z głębi lądu diamenty przez miliony lat. Około 95\% diamen- } \\
\text { tów ma jakość jubilerską }\end{array}$ \\
\hline
\end{tabular}

Źródło: opracowanie własne na podstawie strony internetowej: http://www.dicholding.com/pl/diament/ogolne-informacje/zoa-diamentow (dostęp: 27.07.2014).

W Afryce diamenty występują i są eksploatowane także w takich regionach jak: Lesoto, Zair, Angola, Tanzania, Republika Środkowoafrykańska, a dalej na północ w rejonie równika są wydobywane w Ghanie, na Wybrzeżu Kości Słoniowej, w Burkina Faso, Gwinei, Liberii i Sierra Leone. Z kolei najważniejsze sortownie diamentów należą do następujących firm: De Beers, Rio Tinto, Alrosa i Dominion Diamonds (rys. 5). I tak, na przykład sortownie diamentów De Beers obsługują kopalnie południowoafrykańskie: Windhuk, Gaborone i Kimberley, a sortownia londyńska jest aktualnie przenoszona do Botswany. 


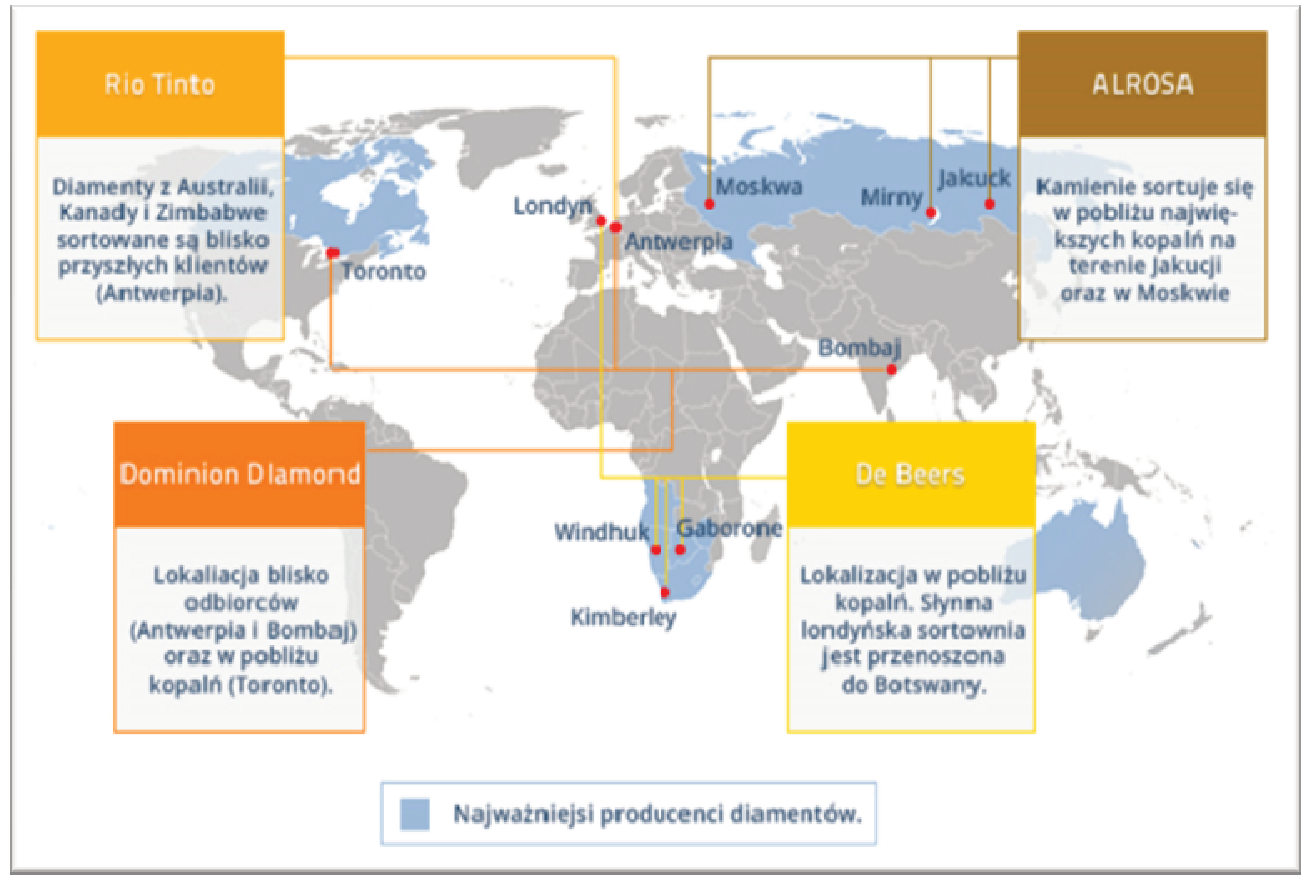

Rys. 5. Światowe ośrodki sortowania diamentów

Fig. 5. World diamond sorting centers

Źródło: Bain \& Co., The Global Diamond Report 2013, Nowy Jork, 2013, s. 33, (dostęp 12.10.2014).

\section{GIEŁDY DIAMENTÓW}

Historia giełdy diamentów w Antwerpii sięga XIII wieku. Obecnie giełda ta znana jest pod nazwą World Diamond Center i jest największą giełdą diamentów na świecie. Ma główną siedzibę w Holandii i oddział w Belgii. Operuje na niej obecnie około 1500 spółek zajmujących się handlem diamentami. W 2013 r. wolumen obrotu na tej giełdzie był równy 56 mld USD. Innymi centrami obrotu diamentami na świecie są ${ }^{16}$ :

1. Diamant-Club (Wiedeń/Austria);

2. Hong Kong Diamond Bourse (Hongong/Chiny);

3. Shanghai Diamond Exchange (Szanghaj/Chiny);

4. The London Diamond Bourse and Club (Londyn/Wielka Brytania);

5. Diamant und Edeldteinbörse Idar-Oberstein (Idar-Obertstein/Niemcy);

6. Bharat Diamond Bourse (Bombaj/Indie);

7. The Israel Diamond Exchange (Ramat-Gan/Izrael);

8. The New Israel Club for Commerce in Diamonds (Ramat-Gan/Izrael);

9. The Israel Precious Stones \& Diamond Exchange (Ramat-Gan/Izrael);

\footnotetext{
${ }^{16} \mathrm{Na}$ podstawie strony internetowej: http://www.ajediam.com/International_Diamond_Center.html (dostęp: 17.09.2014).
} 
10. Borsa Diamnati d'Italia (Milan/Włochy);

11. Tokyo Diamond Exchange (Tokio/Japonia);

12. Vereniging Beurs Voor Den Diamanthandel (Amsterdam/Holandia);

13. Diamond Chamber of Russia (Moskwa/Rosja);

14. Diamond Exchange of Singapore (Singapur);

15. Bangkok Diamonds and Precious Stones Exchange (Bangkok/Tajlandia);

16. Diamond Dealers Club of South Africa (Johannesburg/Republika Południowej Afryki);

17. Diamond Centre South Africa (Johannesburg/Republika Południowej Afryki);

18. Dubai Diamond Exchange (Dubaj/Zjednoczone Emiraty Arabskie);

19. Diamond Club West Coast (Los Angeles/Stany Zjednoczone);

20. Diamond Bourse of Southeast of United States (Miami/Stany Zjednoczone);

21. Diamond Dealers Club (Nowy Jork/Stany Zjednoczone).

Wyróżnia się też 6 największych centrów $(h u b)$ obrotu diamentami na świecie, spośród których największym jest Antwerpia, będąca najważniejszym centrum obrotu diamentami, współpracującym z 4 giełdami diamentów i około 1500 firmami działającymi w branży diamentów (tab. 8).

Tabela 8. Największe centra diamentów na świecie (dane na koniec 2012 r.)

Table 8. The largest diamond centers in the world (at the end of 2012.)

\begin{tabular}{|l|c|l|}
\hline $\begin{array}{l}\text { Lokali- } \\
\text { zacja }\end{array}$ & $\begin{array}{c}\text { Obrót } \\
\text { w ciągu roku } \\
\text { w mld USD }\end{array}$ & \multicolumn{1}{c|}{ Uwagi } \\
\hline $\begin{array}{l}\text { Nowy } \\
\text { Jork }\end{array}$ & $35-40$ & $\begin{array}{l}\text { Około 2600 odbiorców. Najważniejsze centrum dla klientów } \\
\text { biznesowych }\end{array}$ \\
\hline $\begin{array}{l}\text { Antwer- } \\
\text { pia }\end{array}$ & $50-55$ & $\begin{array}{l}\text { Najważniejsze centrum diamentów na świecie. Współpraca z 4 } \\
\text { giełdami diamentów i około 1500 firmami działający w branży } \\
\text { diamentów }\end{array}$ \\
\hline $\begin{array}{l}\text { Tel } \\
\text { Awiw }\end{array}$ & $22-27$ & Około 3200 odbiorców biznesowych \\
\hline Dubaj & $40-45$ & $\begin{array}{l}\text { Około 500 odbiorców regionalnych i międzynarodowych. } \\
\text { Najszybciej rozwijające się centrum }\end{array}$ \\
\hline Bombaj & $25-30$ & $\begin{array}{l}\text { Około 2500 odbiorców biznesowych. Odpowiada za 60\% } \\
\text { diamentów eksportowanych z Indii }\end{array}$ \\
\hline $\begin{array}{l}\text { Hong- } \\
\text { kong }\end{array}$ & $30-35$ & $\begin{array}{l}\text { Około 400 klientów biznesowych. Najważniejsze centrum dla } \\
\text { firm zajmujących się cięciem i polerowaniem diamentów } \\
\text { w Azji }\end{array}$ \\
\hline
\end{tabular}

Źródło: Bain \& Co., The Global Diamond Report 2013, s. 40, (dostęp 12.10.2014). 


\section{INDEKSY NA RYNKU DIAMENTÓW}

Na rynku diamentów, podobnie jak na rynkach finansowych, stworzono specjalistyczne indeksy. Jednym z częściej stosowanych jest Diamond Index (DPI) ${ }^{17}$, którego wartość wzrosła o 23\% w 2011 r., a w 2010 r. - o 14\%. W kolejnych latach 2012 i 2013 indeks ten odnotował stratę w wysokości odpowiednio: $-6,5 \%$ i -3,4\%. W kalkulacji DPI uwzględnia się przeciętną cenę jednego karata w obrocie detalicznym. Ceny diamentów nadsyłane są przez wybrane firmy jubilerskie z całego świata. Diamenty stanowiące bazę do wyliczenia indeksu podzielone są na różne kategorie pod względem wagi, koloru i przezroczystości.

$\mathrm{Na}$ rysunku 6 przedstawiono znormalizowaną wartość indeksu DPI oraz WIG20 w okresie styczeń 2006 - lipiec 2014. W okresie tym DPI zyskał na wartości 58,1\%, podczas gdy indeks WIG20 stracił 14,4\%.

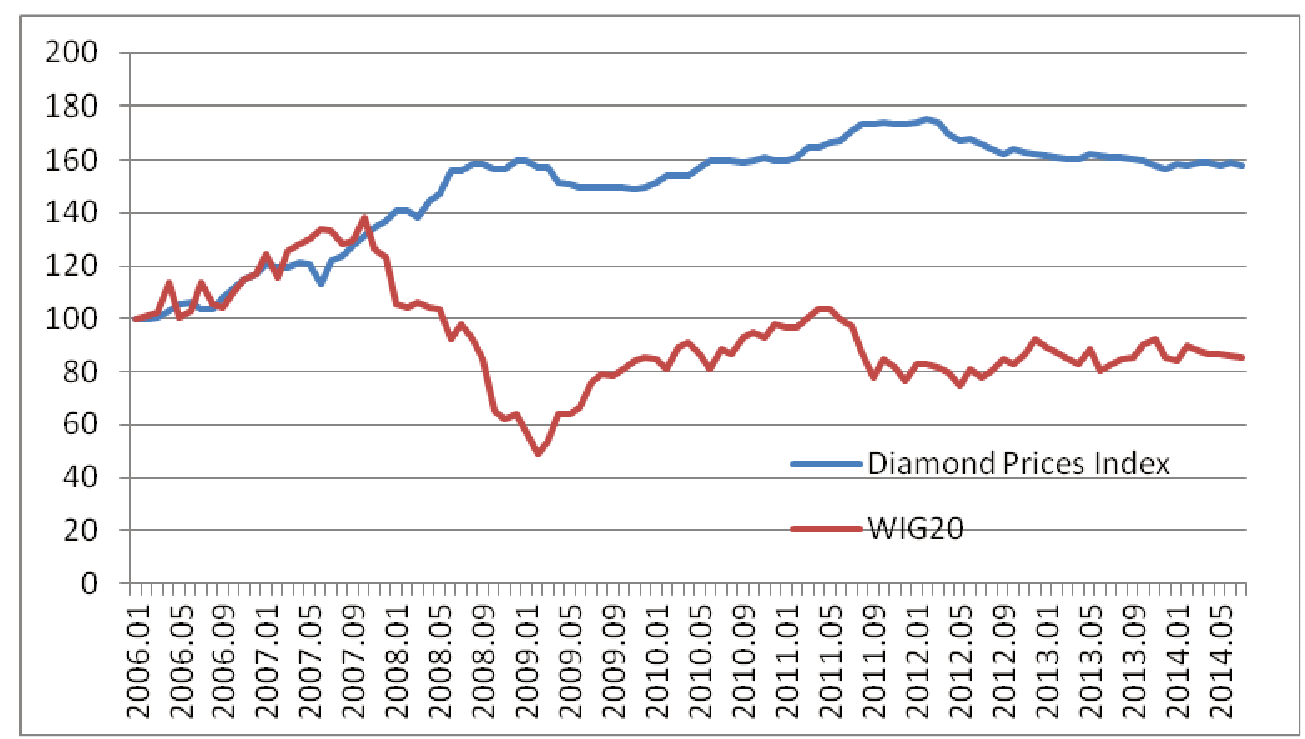

Rys. 6. Zmiana wartości indeksu Diamond Prices Index i indeksu WIG20 w okresie styczeń 2006 lipiec 2014

Fig. 6. Change of the value of the Diamond Prices Index and the WIG 20 index in the period January 2006 - July 2014

Diamond Prices Index (DPI) jest indeksem cen na rynku diamentów. Bierze się w nim pod uwagę średnie ceny detaliczne za karat luźnych diamentów, uzyskane od jubilerów na całym świecie. Ceny oblicza się dla grup z uwzględnieniem mas, jak również koloru i jasności.

Źródło: strona internetowa: http://www.diamondse.info/diamonds-price-index.asp (dostęp: 29.07.2014).

\footnotetext{
${ }^{17}$ W skład indeksu wchodzą różnego rodzaju brylanty od 0,9 karata do 4 karatów, różnej barwie i czystości. Szczegółowy skład indeksu można znaleźć na stronie internetowej: http://www.idexonline.com/ Diamond_Index_Drivers.asp (dostęp: 27.02.2012).
} 
Innym indeksem stosowanym na rynku diamentów jest Polished Prices, stworzony w 2001 r. i obejmujący ceny diamentów o wadze 0,3-3 ct. Jego wartości z okresu 1.01.2002-10.09.2014 przedstawiono na rysunku 7. Na uwagę zasługuje duża zmiana wartości tego indeksu w okresie 7.02.2011-30.07.2011, kiedy to indeks zwyżkował z poziomu 130,41 pkt do 171,26 pkt, czyli o $31,32 \%$.

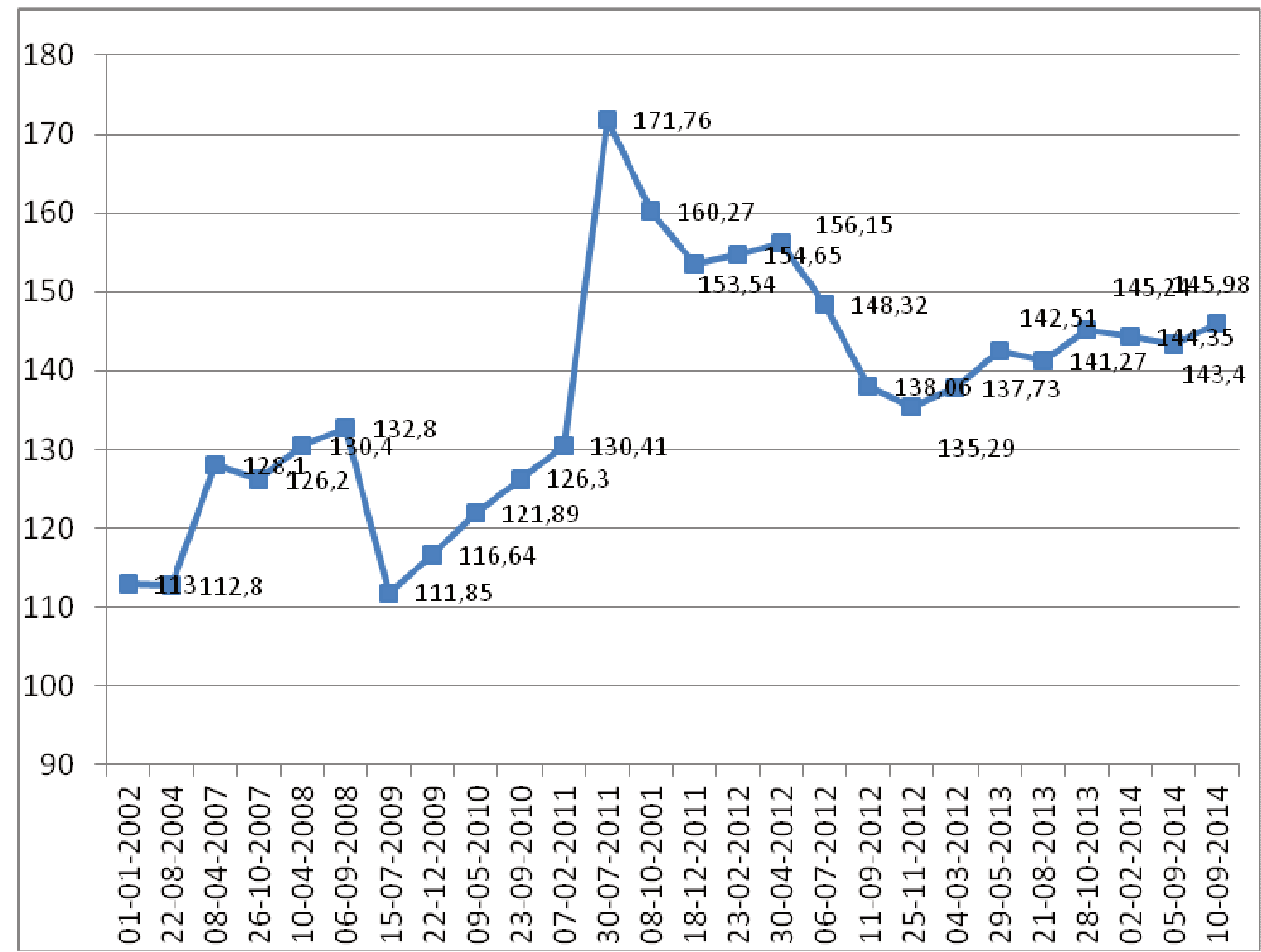

Rys. 7. Zmiana wartości indeksu Polished Prices w okresie 01.01.2002-10.09.2014

Fig. 7. Change of the value of Polished Prices Index in the period 01.01.2002-09.10.2014

Źródło: strona internetowa: http://www.israelidiamond.co.il/english/PolishedIndex.aspx? boneid=1759\&period=0\#anc1 (dostęp: 17.09.2014).

Następnym indeksem na rynku diamentów jest Diamond Index, składający się z 15 subindeksów obejmujących ceny różnych grup diamentów (tab. 9). Wykres indeksu Diamond Prices został przedstawiony na rysunku 8. 
Tabela 9. Subindeksy na rynku diamentów tworzące indeks Diamond Prices

Table 9. Sub-indices in the market of diamonds composers of Diamond Prices index

\begin{tabular}{|c|c|c|c|c|c|}
\hline Lp. & Szlif typu & ct & Kolor & Barwa & $\begin{array}{c}\text { Waga w } \\
\text { indeksie (\%) }\end{array}$ \\
\hline 1 & Okragły & $1,00-1,49$ & D-K & IF-I1 & 12,06 \\
\hline 2 & Okragły & $2,00-2,49$ & D-K & IF-SI3 & 8,18 \\
\hline 3 & Okragły & $1,50-1,99$ & D-K & IF-SI2 & 7,00 \\
\hline 4 & Princessa & $1,00-1,49$ & D-I & WS1-SI2 & 2,87 \\
\hline 5 & Okragły & $3,00-3,49$ & D-J & IF-SI2 & 2,71 \\
\hline 6 & Okragły & $0,70-0,89$ & D-H & WS2-SI2 & 2,04 \\
\hline 7 & Okrąły & $0,50-0,69$ & D-G & WS2-SI1 & 1,71 \\
\hline 8 & Princessa & $2,00-2,49$ & E-I & WS2-SI1 & 1,70 \\
\hline 9 & Princessa & $1,50-1,99$ & E-I & WS2-SI2 & 1,36 \\
\hline 10 & Okragły & $0,90-0,99$ & D-H & VS1-SI2 & 1,00 \\
\hline 11 & Szmaragdowy & $1,00-1,49$ & E-G & WS2-SI1 & 0,84 \\
\hline 12 & Okrągły & $5,00-5,99$ & D-J & IF-SI2 & 0,74 \\
\hline 13 & Szmaragdowy & $5,00-5,99$ & D-J & IF-VS1 & 0,61 \\
\hline 14 & Bagietka & $1,00-1,49$ & E-G & VS1-VS2 & 0,38 \\
\hline 15 & Okragły & $4,00-4,99$ & D-I & IF-SI1 & 0,32 \\
\hline
\end{tabular}

Źródło: strona internetowa: http://www.idexonline.com/Diamond_Index_Drivers.asp (dostęp: 17.09.2014). 


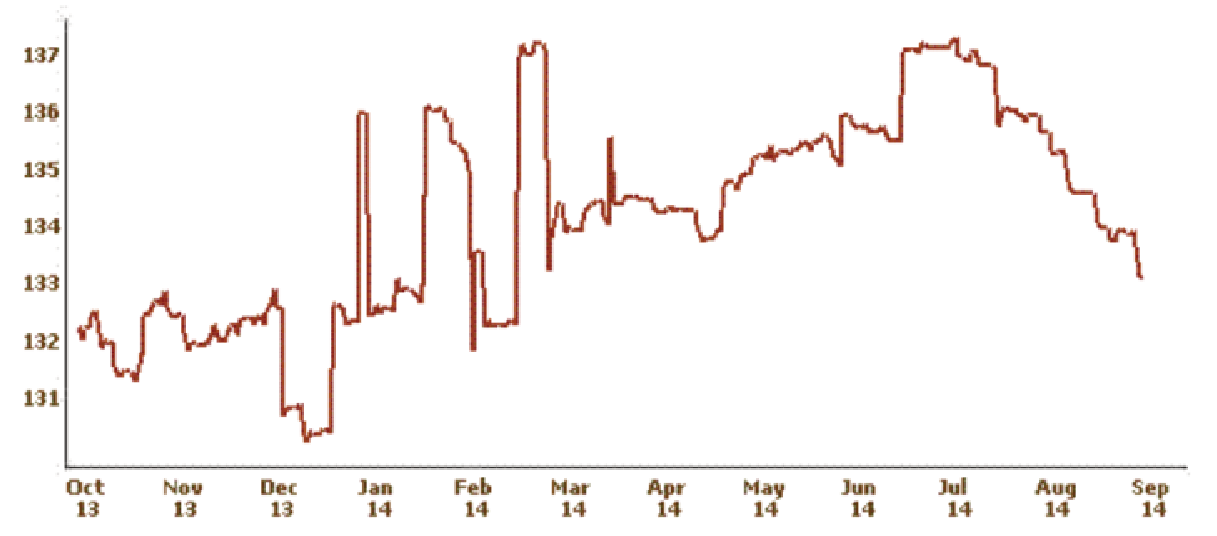

Rys. 8. Zmiana indeksu Diamond Prices w okresie od października 2013 r. do 17 września 2014 r.

Fig. 8. Change of Diamond Prices Index in the period: October 2013 - 17 September 2014

Źródło: strona internetowa: http://www.idexonline.com/Diamond_Index_Drivers.asp (dostęp: 17.09.2014).

Z analizy subindeksów tworzących indeks Diamond Prices wynika, że najbardziej spadł wskaźnik kamieni małych, czyli o masie 0,50-0,69 ct, a najbardziej zdrożały ceny kamieni o masie 1-1,49 ct, czyli takich, od których wielu uczestników rynku zaczyna mówić o kamieniach inwestycyjnych ${ }^{18}$.

Kolejnym indeksem stworzonym przez jedną z największych firm operujących na rynku diamentów jest Rapaport Diamond Trade Index uwzględniający ceny kamieni o wadze jednego karata. Indeks ten od swojego szczytu ustanowionego w lipcu $2011 \mathrm{r}$. spadł o $27 \%$ do końca sierpnia 2014 r. W tym samym okresie inny indeks publikowany przez firmę Rapaport, obejmujący ceny kamieni trzykaratowych, stracił 23\% na wartości, podczas gdy ceny kamieni o wadze 0,3 karata spadły jedynie o $13 \%{ }^{19}$.

Rynek brylantów nie ogranicza się jedynie do obrotu tymi kamieniami. Można także zainwestować $\mathrm{w}$ akcje kopalni brylantów ${ }^{20}$ lub nabyć certyfikaty inwestycyjne funduszy inwestujących na rynku diamentów. W Polsce usługę taką prowadzi kilka biur maklerskich. Na rysunku 9 przedstawiona została stopa zwrotu z akcji kopalni diamentów Rockwell Diamods (RDI) i indeksu S\&P 500 w okresie od połowy 1994 r. do końca sierpnia 2014 r. W analizowanym okresie stopa zwrotu z indeksu giełdowego wynosiła 332\%, podczas gdy cena akcji kopalni straciła na wartości $82 \%$. Na wykresie 9 doskonale widoczna jest cykliczność panująca na rynku akcji kopalni diamentów, objawiająca się okresowymi silnymi zwyżkami cen akcji RDI. Z kolei na wykresie 10 zaprezentowano po-

\footnotetext{
${ }^{18}$ E. Bednarz, Rynek diamentów jest w rękach Hong Kongu, „Puls Biznesu”, 17.09.2014, s. 21.

${ }^{19}$ E. Erheriene, Diamond prices decline for sixth month in row, „Wall Street Journal”, 18.09.2014, s. 22.

${ }^{20}$ Jako przykład akcji kopalni diamentów można podać Rockwell Diamonds z Afryki Południowej notowanej na giełdzie w Toronto. $\mathrm{Z}$ kolei funduszem inwestycyjnym specjalizującym się w inwestycjach na rynku diamentów o wadze pięć i więcej caratów jest KPR Diamond Fund.
} 
równanie stóp zwrotu z akcji wybranych kopalni diamentów w okresie 17.09.200917.09.2014 notowanych na giełdzie w Londynie. Najwyższą stopę zwrotu w analizowanym okresie przyniosły akcje Gemfields PLC - wyniosła ona 870,73\%.

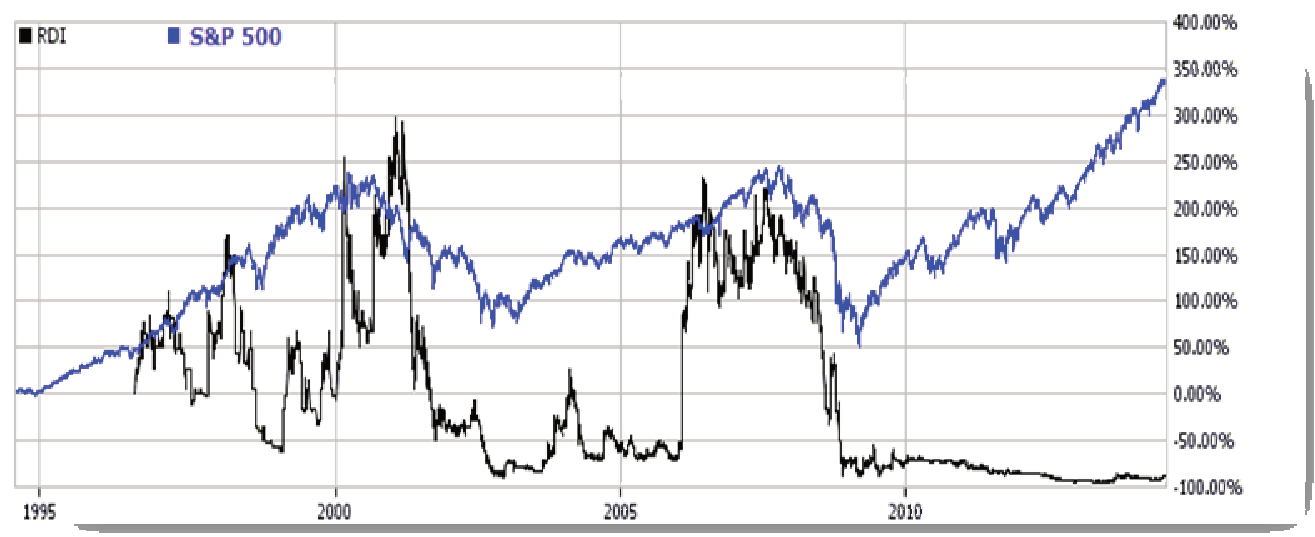

Rys. 9. Porównanie stop zwrotu akcji kopalni diamentów Rockwell Diamonds (RDI) i indeksu S\&P 500 w okresie od polowy 1994 r. do końca sierpnia 2014 r.

Fig. 9. Comparison of rates of return of the diamond mine Rockwell Diamonds (RDI) stocks and the S \& P 500 in the period from mid 1994 to end of August 2014

Źródło: strona internetowa: http://web.tmxmoney.com/charting.php?qm_page=44614\&qm_symbol =RDI (dostęp: 29.07.2014). 


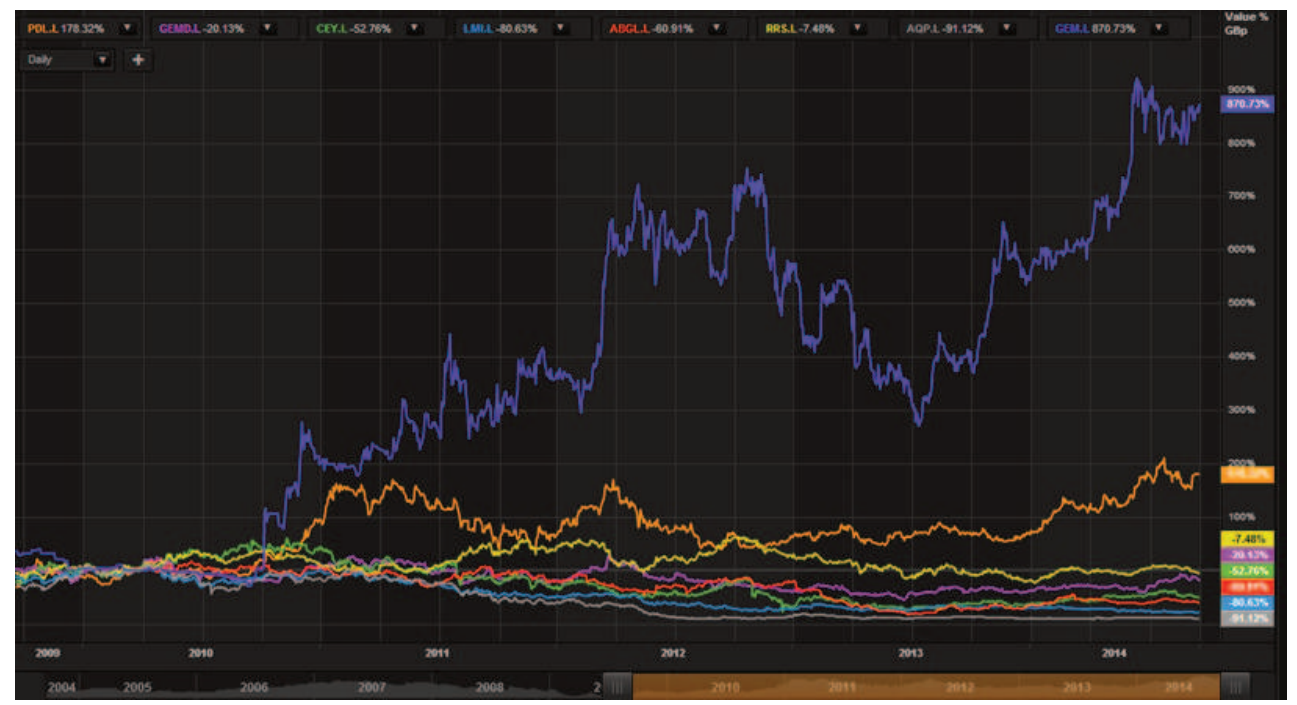

Rys. 10. Porównanie stóp zwrotu z akcji wybranych kopalni diamentów na przestrzeni 17.09.2009 17.09.2014

Fig. 10. Comparison of rates of return on the selected diamond mine shares in the period of 17.09.2009-17.09.2014

Objaśnienia (skrót stosowany na wykresie, nazwa firmy i procentowy wzrost akcji w ciągu 5 lat): GEM.L - Gemfields PLC - 870,73\%; PDL.L - Petra Diamonds - 178, 32\%; RRS.L - Randgold Resources - (-7,48\%); GEMD.L - Gem Diamonds - (-20,13\%); CEY.L - Centamin PLC - ($52,76 \%)$; ABGL.L - African Barrick Gold PLC - (-60,91\%); LMI.L - Lonmin PLC - (-80,63\%); AQP.L - Aquarius Platinum - (-91,12\%)

Źródło: Reuters.

$\mathrm{Na}$ świecie notowanych jest wiele akcji spółek zajmujących się produkcją diamentów. Piętnaście największych z tych, które zaklasyfikowano do sektora wydobycia diamentów, to (kapitalizacja podana w mln USD na dzień 17.09.2014 r. $)^{21}$ :
1. Alrosa - 7106
2. Petra Diamonds $-1632^{22}$,
3. Dominion Diamonds - 1153,
4. Lucara - 843,
5. Gem Diamonds - 449,
6. Stornway Diamonds - 386,
7. SF Diamonds - 352,
8. Firestone Diamonds - 183,
9. Kennady Diasmonds - 156,

\footnotetext{
${ }^{21}$ Na podstawie danych z serwisu Reuters.

${ }^{22}$ To właśnie w kopalniach tej firmy wydobyto w ostatnim czasie jedne z największych diamentów. W lipcu 2014 .r wykopany został w Culliman w Republice Południowej Afryki błękitny diament o wadze 122,52 ct, który w sierpniu tego samego roku sprzedano za kwotę 27,6 mln USD (czyli 225269 USD za jeden karat). W sierpniu 2014 r. spółka poinformowała o wydobyciu białego diamentu o wadze 238,02 ct Na podstawie: E. Erheriene, Diamond prices decline for sixth month in row, ,Wall Street Journal”, 18.09.2014, s. 22.
} 
10. Diamante Minerals - 153,

11. Lucapa Diamonds -63 ,

12. Diamcor Mining -47 ,

13. Obtala Resources -42 ,

14. Diamondcorp - 34,

15. Trans Hex Group - 33.

\section{REGRESJA INDEKSU DPI W OKRESIE STYCZEŃ 2006 - LIPIEC 2014}

Regresję indeksu DPI z wykorzystaniem modelu regresji liniowej w okresie styczeń 2006 - lipiec 2014 (dane w układzie miesięcznym) przedstawiono na rysunku 11. Otrzymano następujące rezultaty. Wartość parametru $a$ jest równa 160,72 (błąd 3,25), a parametru $b-0,75$ (błąd 0,05 ) przy współczynniku $R^{2}$ na poziomie 0,66 .

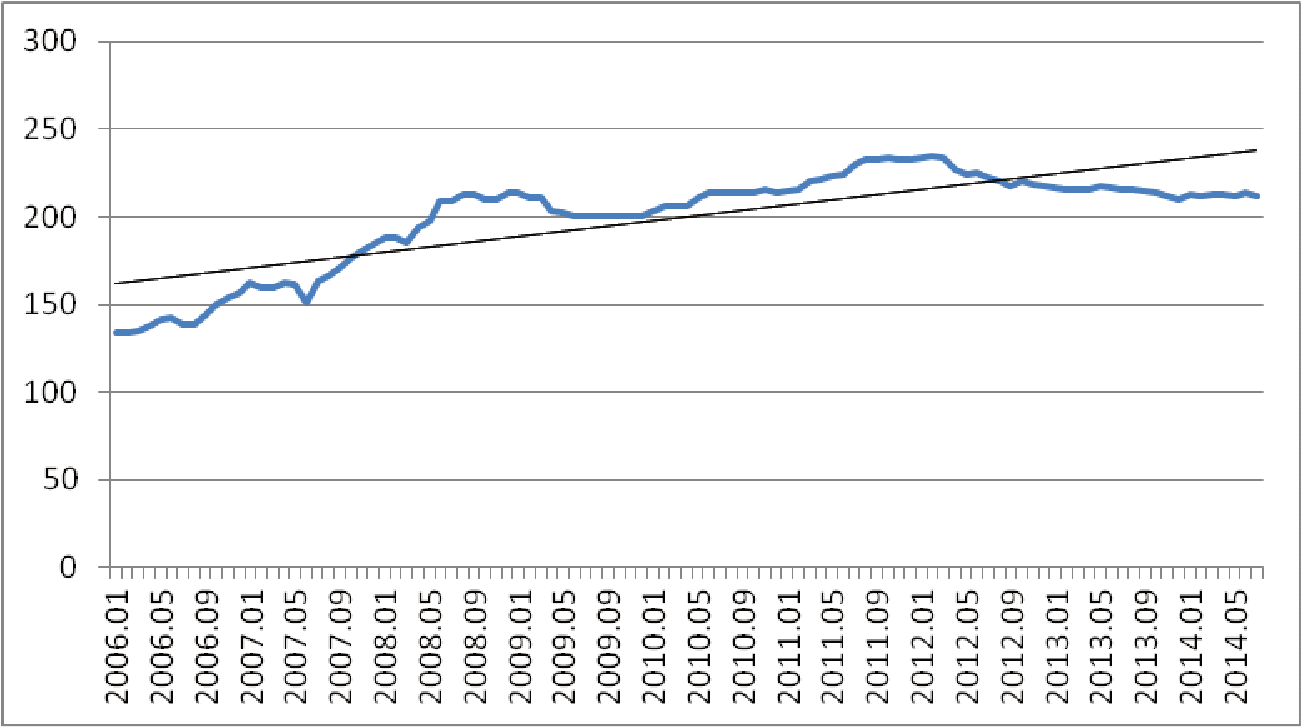

Rys. 11. Indeks Diamond Prices Index i prosta dopasowana metodą najmniejszych kwadratów w okresie styczeń 2006 - lipiec 2014

Fig. 11. Diamond Prices Index and simple method of least squares fit in the period: January $2006-$ July 2014

Źródło: opracowanie własne

W wypadku zastosowania regresji metodą wielomianową współczynnik $R^{2}$ jest wyższy i wynosi 0,92 (rys. 12). 


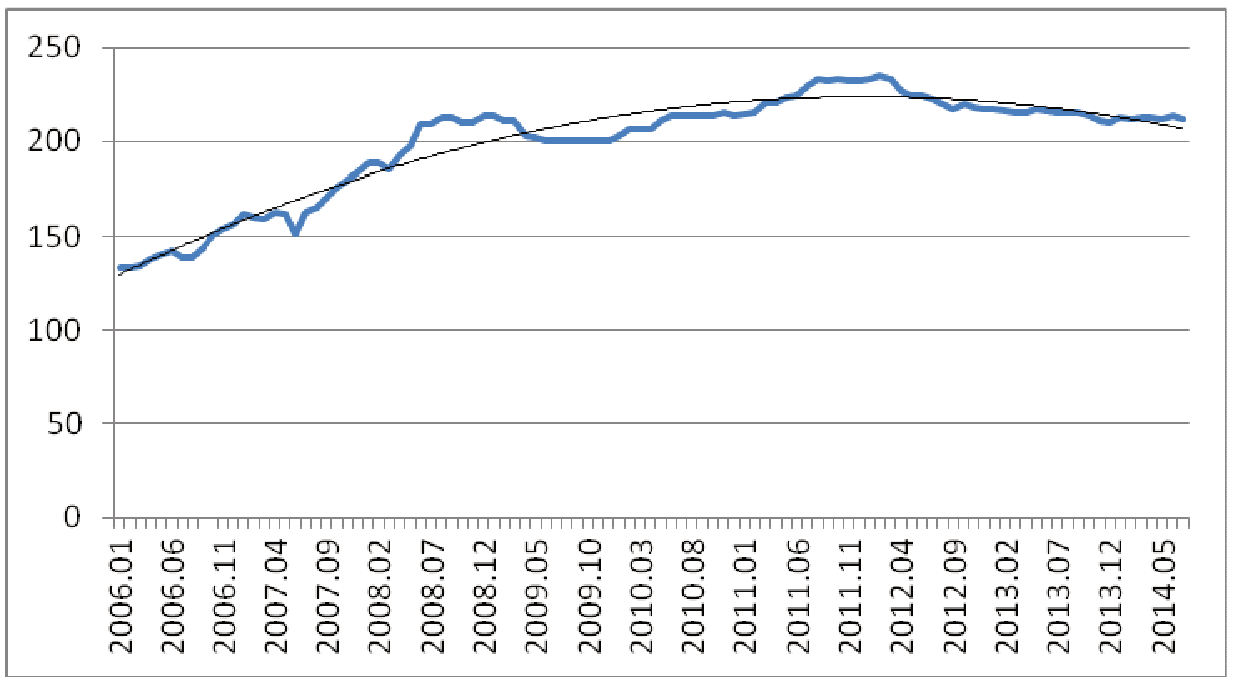

Rys. 12. Indeks Diamond Prices Index i prosta dopasowana metodą wielomianową w okresie styczeń 2006 - lipiec 2014 (dane w układzie miesięcznym)

Fig. 12. Diamond Prices Index and simple polynomial fitting method in the period January 2006 July 2014 (data on a monthly basis)

Źródło: opracowanie własne

\section{ZAKOŃCZENIE}

Rynek diamentów należy do segmentu inwestycji alternatywnych, który rozwija się bardzo dynamicznie od początku kryzysu finansowego. Prognozy dotyczące wielkości wydobycia diamentów w najbliższym czasie są optymistyczne. Pewnym mankamentem tego rynku jest jego oligopolistyczny charakter, co z pewnością przyczynia się do takiego, a nie innego poziomu cen na giełdach diamentów. Rynek diamentów jest na tyle dużym rynkiem inwestycji alternatywnych, że doszło do wykształcenia giełd i centrów obrotu tymi kamieniami, a także publikuje się specjalistyczne indeksy obejmujące ceny diamentów o różnych wagach. Na wielu giełdach publikowane są specjalistyczne indeksy obejmujące ceny określonych grup diamentów - inną grupą podmiotów publikujących podobne indeksy są firmy operujące na rynku diamentów na przykład Rapaport. Zastosowanie diamentów do budowy portfela inwestycyjnego przyczynia się do przesunięcia granicy portfeli efektywnych - w ten sposób przy takim samym ryzyku inwestycyjnym możliwe jest uzyskanie wyższej stopy zwrotu z inwestycji. Z kolei wykorzystanie indeksów cen diamentów pozwala na dokonanie porównania stóp zwrotu cen na rynku diamentów ze stopami zwrotu na rynku akcji, obligacji czy też innych aktywów.

\section{LITERATURA}

[1] Alrosa, Diamonds - survey 2014, Moskawa, wrzesień 2014 (j. angielski) .

[2] Bain \& Co., The Global Diamond Report 2013, http://www.bain.com/publications/ articles/global-diamond-report-2013.aspx (dostęp: 02.09.2014).

[3] Bednarz E., Rynek diamentów jest w rękach Hongkongu, „Puls Biznesu”, 17.09.2014, s. 21. 
[4] Borowski K., Bombol M., Inwestycje na rynku wina inwestycyjnego oraz diamentów, [w:] Badania polskiej klasy wyższej. Problemy, diagnozy, dylematy, red. M. Bombol, Oficyna Wydawnicza SGH, Warszawa 2012, s. 225-238.

[5] Eid A., Minerały i skamieniałości, Arkady, Warszawa 2000.

[6] Erheriene E., Diamond prices decline for sixth month in row, „Wall Street Journal”, 18.09.2014, s. 22.

[7] Euromonitor, Diamond research, http://www.euromonitor.com/jewellery (dostęp: 01.09.2014).

[8] Mazurkiewicz P., Brylanty sq wieczne. I drożeja, „Rzeczpospolita”, 18.02.2014, s. B6.

[9] Rapaport, Diamond in the world 2013 - Nowy Jork 2014 (j. angielski) . .

[10] Wilson J., England A., Rare gems add lustre to rally in diamonds, „Financial Times”, 06.09.2014, s. 11.

\section{Strony internetowe}

[1] http://www.ajediam.com/International_Diamond_Center.html (dostęp: 19.09.2014).

[2] http://inwestycje.pl/diamenty/Rynek-diamentow---podsumowanie-i-prognozy;225054;0.html (dostęp: 19.09.2014).

[3] http://pl.wikipedia.org/wiki/Faseta (dostęp: 22.07.2014)..

[4] http://www.ekonomia24.pl/artykul/706159,785085-Zloto-zdrozeje-w-2012--Ale-czas-nadiamenty.html (dostęp: 27.02.2014). .

[5] http://www.dicholding.com/pl/diament/ogolne-informacje/zoa-diamentow (dostęp: 27.07.2014).

[6] http://www.ajediam.com/International_Diamond_Center.html (dostęp: 17.09.204).

[7] http://www.idexonline.com/Diamond_Index_Drivers.asp (dostęp: 27.02.2012).

[8] http://www.israelidiamond.co.il/english/PolishedIndex.aspx?boneid=1759\&period=0\#anc1 (dostęp: 17.09.2014).

[9] http://web.tmxmoney.com/charting.php?qm_page=44614\&qm_symbol=RDI (dostęp: 29.07.2014)

[10] http://www.forbes.pl/diamenty-w-odwrocie-juz-wkrotce-zacznie-brakowacdiamentow,artykuly,165840,1,1.html (dostęp: 19.09.2014).

\section{ANALYSIS OF INVESTMENT CONDITIONS IN THE DIAMONDS MARKET}

The article presents rough diamond market development, cut and polished diamonds market development as well as the diamond jewellery market. Up to 2011 diamonds market belonged to one of the fastest growing segments of alternative investments, mainly due to investors seeking opportunities to invest surplus funds in other areas of the financial market than the stock market, bonds, commodities or currencies. Investments in the diamond market also include the purchase of shares of companies operating in this segment, i.e. mining companies and intermediaries. Diamond market is one of the few alternative investment markets of the developed system of diamonds exchange, as well as having a wide classification of traded objects.

The article shows selected indexes used in the diamond market as well as the rate of return of the shares of selected diamond mines. An analysis has been carried out of rates of return of the index Diamond Prices Index with the index WIG 20 in the period January 2006 July 2014 as well as linear regression and polynomial regression of Diamond Prices Index in the same period. The results obtained clearly indicate that during the analyzed period, the return on the index DPI was positive and amounted to $58.1 \%$, while the rate of return on an equity index Polish WIG 20 was negative and equal to $14.4 \%$. Results of the polynomial regression of DPI index are significantly better - the coefficient $R^{2}$ equals to 0.92 while in the linear regression method amounted to 0.66 . 
Keywords: diamond market, diamonds, diamond jewellery, diamond exchanges, rate of return in diamonds, alternative investments, alternative investments.

\section{DOI: $10.7862 /$ rz.2014.mmr.44}

Tekst złożono w redakcji: listopad 2014

Przyjęto do druku: grudzień 2014 